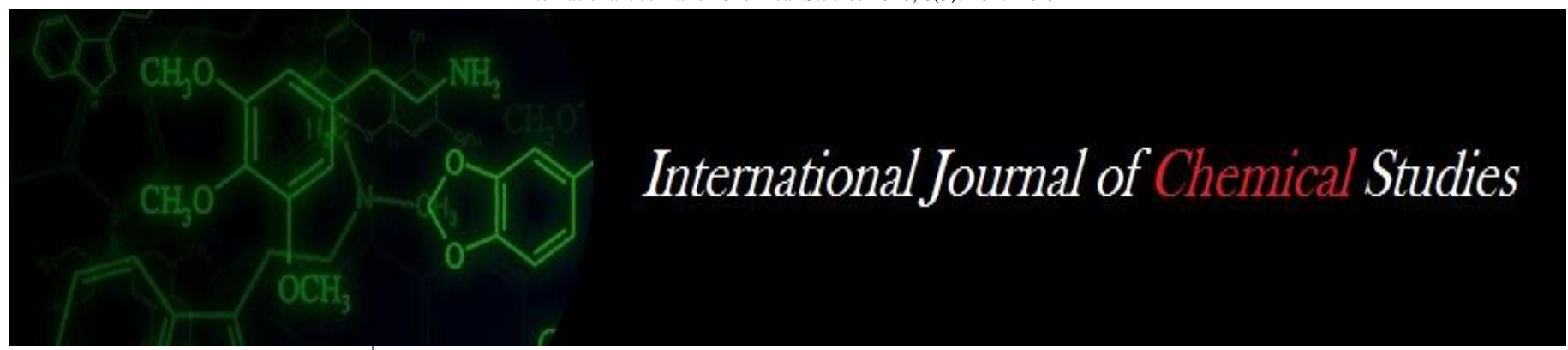

P-ISSN: 2349-8528

E-ISSN: 2321-4902

www.chemijournal.com

IJCS 2020; 8(3): 2647-2649

(C) 2020 IJCS

Received: 26-03-2020

Accepted: 27-04-2020

Kanheya Lal Yadav

Department of Floriculture and

Landscaping College of

Horticulture \& Forestry,

Jhalrapatan City Jhalawar,

Rajasthan, India

\section{Anil Sharma}

Department of Floriculture and

Landscaping College of

Horticulture \& Forestry,

Jhalrapatan City Jhalawar,

Rajasthan, India

\section{Ashutosh Mishra}

Department of Floriculture and

Landscaping College of

Horticulture \& Forestry,

Jhalrapatan City Jhalawar,

Rajasthan, India

Kamlesh Yadav

Department of Floriculture and

Landscaping College of

Horticulture \& Forestry,

Jhalrapatan City Jhalawar,

Rajasthan, India
Corresponding Author: Kanheya Lal Yadav Department of Floriculture and Landscaping College of Horticulture \& Forestry, Jhalrapatan City Jhalawar, Rajasthan, India

\section{Effect of nitrogen and phosphorus on flowering and yield of gaillardia (Gaillardia pulchella Foug.) CV. Local yellow under Jhalawar condition}

\author{
Kanheya Lal Yadav, Anil Sharma, Ashutosh Mishra and Kamlesh Yadav
}

DOI: https://doi.org/10.22271/chemi.2020.v8.i3al.9614

\begin{abstract}
The studies were carried out to study the effect of nitrogen and Phosphorus on flowering and yield of Gaillardia (Gaillardia pulchella Foug.) cv. Local Yellow under Jhalawar condition. The experiment consisting 16 treatments combination with two factors i.e. nitrogen with four levels (control, $100 \mathrm{~kg} \mathrm{ha}^{-1}$, $200 \mathrm{~kg} \mathrm{ha}^{-1}$ and $300 \mathrm{~kg} \mathrm{ha}^{-1}$ ) and phosphorus with four levels (control, $100 \mathrm{~kg} \mathrm{ha}^{-1}, 200 \mathrm{~kg} \mathrm{ha}^{-1}$ and 300 $\left.\mathrm{kg} \mathrm{ha}^{-1}\right)$ in Factorial Randomized Block Design with three replications. The individual application of nitrogen treatment $\mathrm{N}_{3}\left(\mathrm{~N} 300 \mathrm{~kg} \mathrm{ha}^{-1}\right.$ ) Earliest first flower opening (60.93 days), Earliest $50 \%$ flowering (91.26 days), maximum flower diameter $(6.67 \mathrm{~cm})$, maximum number of flower per plant (111.67), maximum weight of flower per plant $(0.437 \mathrm{~kg})$, number of flower per plot maximum (2615.83), maximum weight of flower per plot $(11.53 \mathrm{~kg})$, maximum flower yield $(121.25 \mathrm{q} / \mathrm{ha})$. The individual application of phosphorus treatment $\mathrm{P}_{3}\left(\mathrm{P} 300 \mathrm{~kg} \mathrm{ha}^{-1}\right)$ recorded minimum $(63.25$ days $)$ to first flower opening, earliest (95.25 days) 50\% flowering, maximum flower diameter $(6.56 \mathrm{~cm})$, flowers per plant (108.83), weight of flower per plant $(0.446 \mathrm{~kg})$, number of flower per plot $(2574.83)$, flower weight per plot $(10.78 \mathrm{~kg})$ and flower yield $(115.08 \mathrm{q} / \mathrm{ha})$.
\end{abstract}

Keywords: Gaillardia, nitrogen, phosphorus, flowering and yield attributes

\section{Introduction}

Gaillardia (Gaillardia pulchella Foug.) popularly known as 'Blanket Flower' or Fire Wheel, belong to the family Asteraceae and is native to Central and Western United States, The flowers are borne on long thin wire like stems in solitary, well above the sprawling branches underneath, with usually showy heads (4-6 cm diameter). The generic name Gaillardia was proposed by Mr. Gaillard de Marentoneau, the French botanist 18th century. Gaillardia pulchella is diploid $(2 \mathrm{n}=36)$ as reported by Morinaaga et al. (1929) ${ }^{[13]}$ and Gaillardia aristata is diploid (Cooper and Mahony, 1936) ${ }^{[3]}$ and tetraploid, 2n = 78 (Atwood, 1937) ${ }^{[1]}$. Besides its utility in landscape and as cut flowers, Gaillardia is useful in reducing erosion in coastal dune areas (Carig, 1977) ${ }^{[2]}$.

Nitrogen is the most vital element among the major nutrient essentially required for commercial production of flowers. Nitrogen impart green colour to plant, encourages, vegetative growth it is essential constituent of protein, chlorophyll, coenzyme and play important role in synthesis of auxin and phosphorus increased the disease resistance, enhance new cell formation and necessary for root development. Phosphorus is essential constituent of nucleic acid and phytin. Due to deficiency of single element (Phosphorus), the life cycle of plant can't be completed hence, phosphorus is called as "key of life" (Das. 1996) ${ }^{[4]}$.

\section{Materials and Methods}

The field experiment entitled "Effect of Nitrogen and Phosphorous on flowering and yield of gaillardia (Gaillardia pulchella Foug.) cv. Local Yellow under Jhalawar condition" was conducted at the Instructional Farm, Department of Floriculture and Landscaping, College of Horticulture and Forestry, Jhalrapatan, Jhalawar from March 2017 to September 2017. The experiment consisting 16 treatments combinations with two factors i.e. nitrogen with four levels (control, 100, 200 and $300 \mathrm{~kg} \mathrm{ha}^{-1}$ ) and phosphorus with four levels (control, 100, 200 and $300 \mathrm{~kg} \mathrm{ha}^{-1}$ ) in Factorial Randomized Block Design with three replications each. 
The treatment combinations are $\mathrm{T}_{0}=\mathrm{N}_{0} \mathrm{P}_{0}(0 \mathrm{~kg} \mathrm{~N} / \mathrm{ha}+0 \mathrm{~kg}$ $\mathrm{P} / \mathrm{ha}), \mathrm{T}_{1}=\mathrm{N}_{0} \mathrm{P}_{1}(0 \mathrm{~kg} \mathrm{~N} / \mathrm{ha}+100 \mathrm{~kg} \mathrm{P} / \mathrm{ha}), \mathrm{T}_{2}=\mathrm{N}_{0} \mathrm{P}_{2}(0 \mathrm{~kg}$ $\mathrm{N} / \mathrm{ha}+200 \mathrm{~kg} \mathrm{P} / \mathrm{ha}), \mathrm{T}_{3}=\mathrm{N}_{0} \mathrm{P}_{3}(0 \mathrm{~kg} \mathrm{~N} / \mathrm{ha}+300 \mathrm{~kg} \mathrm{P} / \mathrm{ha}), \mathrm{T}_{4}$ $=\mathrm{N}_{1} \mathrm{P}_{0}(100 \mathrm{~kg} \mathrm{~N} / \mathrm{ha}+0 \mathrm{~kg} \mathrm{P} / \mathrm{ha}), \mathrm{T}_{5}=\mathrm{N}_{2} \mathrm{P}_{0}(200 \mathrm{~kg} \mathrm{~N} / \mathrm{ha}+0$ $\mathrm{kg} \mathrm{P} / \mathrm{ha}), \mathrm{T}_{6}=\mathrm{N}_{3} \mathrm{P}_{0}(300 \mathrm{~kg} \mathrm{~N} / \mathrm{ha}+0 \mathrm{~kg} \mathrm{P} / \mathrm{ha}), \mathrm{T}_{7}=\mathrm{N}_{1} \mathrm{P}_{1}(100$ $\mathrm{kg} \mathrm{N} / \mathrm{ha}+100 \mathrm{~kg} \mathrm{P} / \mathrm{ha}), \mathrm{T}_{8}=\mathrm{N}_{1} \mathrm{P}_{2}(100 \mathrm{~kg} \mathrm{~N} / \mathrm{ha}+200 \mathrm{~kg}$ $\mathrm{P} / \mathrm{ha}), \mathrm{T}_{9}=\mathrm{N}_{1} \mathrm{P}_{3}(100 \mathrm{~kg} \mathrm{~N} / \mathrm{ha}+300 \mathrm{~kg} \mathrm{P} / \mathrm{ha}), \mathrm{T}_{10}=\mathrm{N}_{2} \mathrm{P}_{1}(200$ $\mathrm{kg} \mathrm{N} / \mathrm{ha}+100 \mathrm{~kg} \mathrm{P} / \mathrm{ha}), \mathrm{T}_{11}=\mathrm{N}_{2} \mathrm{P}_{2}(200 \mathrm{~kg} \mathrm{~N} / \mathrm{ha}+200 \mathrm{~kg}$ $\mathrm{P} / \mathrm{ha}), \mathrm{T}_{12}=\mathrm{N}_{2} \mathrm{P}_{3}(200 \mathrm{~kg} \mathrm{~N} / \mathrm{ha}+300 \mathrm{~kg} \mathrm{P} / \mathrm{ha}), \mathrm{T}_{13}=\mathrm{N}_{3} \mathrm{P}_{1}$ $(300 \mathrm{~kg} \mathrm{~N} / \mathrm{ha}+100 \mathrm{~kg} \mathrm{P} / \mathrm{ha}), \mathrm{T}_{14}=\mathrm{N}_{3} \mathrm{P}_{2}(300 \mathrm{~kg} \mathrm{~N} / \mathrm{ha}+200$ $\mathrm{kg} \mathrm{P} / \mathrm{ha}), \mathrm{T}_{15}=\mathrm{N}_{3} \mathrm{P}_{3}(300 \mathrm{~kg} \mathrm{~N} / \mathrm{ha}+300 \mathrm{~kg} \mathrm{P} / \mathrm{ha})$.

\section{Results and Discussion}

The result of present study clearly indicate that Earliest first flower opening, Earliest $50 \%$ flowering, maximum flower diameter, maximum number of flower per plant, maximum weight of flower per plant, number of flower per plot maximum, maximum weight of flower per plot, maximum flower yield were significantly increased by individual application of different nitrogen and phosphorus as compare to control. The application of nitrogen $\mathrm{N}_{3}\left(300 \mathrm{~kg} \mathrm{ha}^{-1}\right)$ had earliest first flower opening (60.93 days), earliest $50 \%$ flowering (91.26 days), maximum flower diameter $(6.67 \mathrm{~cm})$ maximum number of flower per plant (111.67), maximum weight of flower per plant $(0.437 \mathrm{~kg})$, number of flower per plot maximum (2615.83), maximum weight of flower per plot $(11.53 \mathrm{~kg})$, maximum flower yield $(121.25 \mathrm{q} / \mathrm{ha})$.

The early induction of flowers with increased application of nitrogen might be due to more synthesis of protein and protoplasm from carbohydrates leading to late accumulation of stored carbohydrates in vegetative parts Lodhi et al. (1993) [9]. Singatkar et al. (1995) [23], Patil et al. (2004) ${ }^{[20]}$ and Karetha et al. (2011) ${ }^{[6]}$ in gaillardia, Monish et al. (2008) ${ }^{[12]}$ in China aster. The application of nitrogen at optimum level attributed to accelerate plant growth and reproductive organs, Sonal et al. (2010) ${ }^{[24]}$ in China aster, Joshi and Barad (2002)

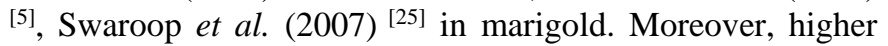
nitrogen content might have accelerated protein synthesis, thus promoting early floral primordial development (Khimani, 1995 in gaillardia) ${ }^{[7]}$. Application of nitrogen the growth of sink tissues and organs (in present case, the flowers) can be limited by short supply of photosynthates from source leaves (Marschner, 1995) ${ }^{[11]}$, which increases stored food material in the tissues, which in turn causes increase in flower stalk length. The results are in close agreement with the result of Tosar (1989) ${ }^{[26]}$, Nagalakshmi and Ravisankar (2002) ${ }^{[17]}$ and Patel et al. (2015) ${ }^{[19]}$ in gaillardia. Its adequate amount is essential to maximize photosynthetic activities for synthesis of carbohydrate in plant and their conversion into plant lipids, which in turn causes increased fresh flower weight (Karetha et al. 2011 in gaillardia) ${ }^{[6]}$, which might have improved the longevity of flower in field condition (Nanjan et al. 1980 in tuberose) ${ }^{[18]}$. Nitrogen is the essential component of protoplasm and chlorophyll materials and its adequate quantity is essential to maximum photosynthetic activities for synthesis of carbohydrate in plant, (Nagaich et al. 2004 in marigold) ${ }^{[16]}$.

The individual application of phosphorus treatment $\mathrm{P}_{3}$ (P 300 $\mathrm{kg} \mathrm{ha} \mathrm{h}^{-1}$ ) recorded minimum (63.25 days) to first flower opening, earliest (95.25 days) 50\% flowering, maximum flower diameter $(6.56 \mathrm{~cm})$, flowers per plant (108.83), weight of flower per plant $(0.446 \mathrm{~kg})$, number of flower per plot (2574.83), flower weight per plot $(10.78 \mathrm{~kg})$ and flower yield (115.08 q/ha). It is well documented that phosphorus is an essential element in reproductive and vegetative growth of plants and thus, the vegetative growth and flowering stimulation increased by applying on gaillardia in present study, Kumar et al. (2002) ${ }^{[8]}$ in China aster. Phosphorus increases in flower size because, phosphorus fertilization might have accelerated photosynthesis during vegetative phase and translocation of photosynthates to various metabolic sinks during reproductive phase, (Singatkar et al. 1995 in gaillardia) ${ }^{[23]}$. Similar founding are, Patil et al. (2004) ${ }^{[20]}$ and Karetha et al. (2011) ${ }^{[6]}$ in gaillardia, Monish et al. (2008) [12] in China aster and Sharma et al. (2010) [22], Maharnor et al. (2011) ${ }^{[10]}$ in marigold. Increased availability of phosphorus in soil might have higher flower weight and phosphorus content in vegetative, Rathod et al. (2003) ${ }^{[21]}$ in gaillardia and phosphorus is also known to have multifarious cellular functions in plants, including signaling and transmembrane metabolic flux and therefore, the secondary metabolism, (Sonal et al. 2010 in China aster) ${ }^{\text {[24], which }}$ increase the weight of flower in the field their conversion into plant lipids and phosphorus fertilization also enhanced translocation and partitioning of assimilates to floral parts, resulting in improved yield attributes, which obviously resulted in higher flower yield (Karetha et al. 2011 in gaillardia) ${ }^{[6]}$.

\section{Conclusion}

The individual application of nitrogen $\mathrm{N}_{3}\left(300 \mathrm{~kg} \mathrm{ha}^{-1}\right)$ and phosphorus $\mathrm{P}_{3}\left(300 \mathrm{~kg} \mathrm{ha}^{-1}\right)$ had earliest first flower opening (60.93 and 63.25 days), earliest 50\% flowering (91.26 and 95.25 days), maximum flower diameter $(6.67$ and $6.56 \mathrm{~cm})$, maximum number of flower per plant (111.67 and 108.23), maximum weight of flower per plant $(0.437$ and $0.446 \mathrm{~kg})$, number of flower per plot maximum (2615.83and 2574.83), maximum weight of flower per plot $(11.53$ and $10.78 \mathrm{~kg}$ ), maximum flower yield (121.25 and $115.08 \mathrm{q} / \mathrm{ha})$.

Table 1.

\begin{tabular}{|c|c|c|c|c|c|c|c|c|}
\hline Treatment & $\begin{array}{c}\text { Days to first } \\
\text { flower opening }\end{array}$ & \begin{tabular}{|c|} 
Days to $50 \%$ \\
flowering
\end{tabular} & \begin{tabular}{c|} 
Flower \\
diameter $(\mathbf{c m})$
\end{tabular} & \begin{tabular}{|c|} 
Number of \\
flower per plant
\end{tabular} & $\begin{array}{c}\text { Weight of flower } \\
\text { per plant (kg) }\end{array}$ & $\begin{array}{c}\text { Number of } \\
\text { flower per plot }\end{array}$ & $\begin{array}{l}\text { Weight of flower } \\
\text { per plot }(\mathrm{kg})\end{array}$ & $\begin{array}{l}\text { Estimated flower } \\
\text { yield (q/ha) }\end{array}$ \\
\hline $\mathbf{N}_{0}$ & 70.92 & 104.54 & 5.38 & 97.67 & 0.358 & 2384.75 & 7.58 & 76.42 \\
\hline $\mathbf{N}_{1}$ & 69.13 & 102.42 & 6.19 & 100.33 & 0.394 & 2450.92 & 8.79 & 92.00 \\
\hline $\mathrm{N}_{2}$ & 67.83 & 100.67 & 6.38 & 104.92 & 0.398 & 2467.00 & 9.35 & 101.83 \\
\hline $\mathrm{N}_{3}$ & 60.93 & 91.26 & 6.67 & 111.67 & 0.437 & 2615.83 & 11.53 & 121.25 \\
\hline SEm \pm & 1.50 & 2.18 & 0.07 & 1.79 & 0.01 & 51.19 & 0.74 & 13.12 \\
\hline C.D. $(\mathrm{P}=0.05)$ & 4.33 & 6.31 & 0.22 & 5.17 & 0.03 & 147.83 & 2.14 & 16.08 \\
\hline $\mathrm{P}_{0}$ & 71.03 & 105.14 & 5.66 & 98.67 & 0.324 & 2380.67 & 8.08 & 70.17 \\
\hline $\mathrm{P}_{1}$ & 68.65 & 101.78 & 6.05 & 100.50 & 0.386 & 2416.00 & 8.27 & 98.33 \\
\hline $\mathrm{P}_{2}$ & 65.88 & 96.98 & 6.34 & 106.58 & 0.431 & 2550.00 & 10.13 & 107.42 \\
\hline $\mathrm{P}_{3}$ & 63.25 & 95.25 & 6.56 & 108.83 & 0.446 & 2574.83 & 10.78 & 115.08 \\
\hline $\mathrm{SEm} \pm$ & 1.50 & 2.18 & 0.07 & 1.79 & 0.01 & 51.19 & 0.74 & 13.12 \\
\hline C.D. $(\mathrm{P}=0.05)$ & 4.33 & 6.31 & 0.22 & 5.17 & 0.03 & 147.83 & 2.14 & 16.08 \\
\hline
\end{tabular}




\section{References}

1. Atwood S. Cellule. 1937; 46:389.

2. Carig RM. Proceedings Florida State Horticulture Science. 1977; 90:180-210.

3. Cooper DC. Mahony KL. American Journal of Botany. 1936; $22: 843$.

4. Das DK. Introductory soil science. Kalyani Publication, 1996, 295-296.

5. Joshi NS, Barad AV. Effect of N, P and Pinching on growth, yield and quality of African marigold (Tagetes erecta L.) cv. Crackerjack. Gujarat Journal Applied of Horticulture. 2002; 1(1):57-65.

6. Karetha KM, Jat G, Singh V, Gajipara NN. Effect of different level of N, P and $\mathrm{K}$ on growth, yield attributes of gaillardia (Gaillardia pulchella) cv. Local Double. Asian Journal of Horticulture, 2011; 6(2):344-347.

7. Khimani RA. A note on self-life studies in gaillardia. Gujarat Agriculture University Research Journal. 1995; 20(2):190-191.

8. Kumar J, Chauhan SS, Singh PV. Response of nitrogen and phosphorus on China aster. Asian Journal of Horticulture. 2002; 9(4):324-328.

9. Lodhi AKS, Tiwari GN. Nutritional requirement of chrysanthemum under field condition. International Journal of Agriculture Science. 1993; 6(4):355-361.

10. Maharnor SI, Chopde N, Thakre S, Raut PD. Effect of nitrogen and pinching on growth and yield of African marigold. Asian Journal of Horticulture. 2011; 1(6):4345 .

11. Marschner H. Mineral Nutritional of Higher Plants. Second edition. Academic press Ltd., London, 1995, 889.

12. Monish M, Umaro VK, Tyagi AK, Meena PM. Effect of nitrogen and phosphorus levels on growth flowering and yield of China aster. Agricultural Sciences Digest. 2008; 2(28):97-100.

13. Morinaaga Y, Fukushima E, Kano T, Yamasaki Y. Reported Gaillardia pulchella diploid. Botanical Magazine Tokyo. 1929; 43:589.

14. Muhammad S, Noorul A. Effect of varies combination of nitrogen, phosphorus and potash an enhancing the flowering time in chrysanthemum (Chrysanthemum morifolium). International Journal and Biosean Science. 2014; 4(10):99-108.

15. Muktanjali J, Paithankar DH, Warde AD, Mohariya A, Ambre TP. Effect of graded levels of nitrogen and phosphorus on growth and flower production of China aster cv. Local. Advanced in Plant Science. 2004; 17(1):163-165.

16. Nagaich KN, Trivedi SK, Lekhi R. Effect of nitrogen and phosphorus on growth, flowering, yield and quality of marigold. Scientific Horticulture. 2004; 8(2):203-209.

17. Nagalakshmi R, Ravisankar C. Effect of spacing and N \& $P$ levels on gaillardia. Karnataka Journal of Horticulture. 2002; 25(27):40-41.

18. Nanjan K, Nambisan KMP, Veeraragavathatham D, Krishnan BM. The effect of nitrogen, phosphorus and potash on the yield of tuberose (Polianthes tuberosa L.). Karnataka Journal of Agriculture Science. 1980; 4(2):221-227.

19. Patel AS, Leua HN, Parekh NS, Patel HC. Effect of integrated nitrogen management on growth, flowering and flower yield of gaillardia (Gaillardia pulchella Foug.) cv. Lorenziana under middle Gujarat condition. Asian Journal Horticulture. 2015; 10(1):126-129.
20. Patil BC, Kulkani BS, Jagdeesh SL, Madalgeri MB. Effect of split application on nitrogen at different stage on growth and flower production in gaillardia on red soil. Karnataka Journal of Horticulture. 2004; 1(1):104-107.

21. Rathod NG, Narwadkar PR, Sajindranath AK, Prabu T. Effect of integrated nutrient management on growth and yield of Gaillardia. Journal of Maharashtra Agricultural Universities. 2003; 27(3):318-319.

22. Sharma AK, Chaudhary SS, Gupta YC. Effect of nitrogen and phosphorus on flowering and yield of African marigold (Tagetes erecta L.). Progressive Agriculture. 2010; 1(10):158-160.

23. Singatkar SS, Sawant RB, Ranpise SA, Wavhal KN. Effect of different levels of $\mathrm{N}, \mathrm{P}$ and $\mathrm{K}$ on growth and flower production of Gaillardia. Journal of Maharashtra Agriculture Universities. 1995; 20(3):392-394.

24. Sonal N, Sehrawat SK, Gupta AK, Kumar S, Lather S. Studies on effect of nitrogen and phosphorus on growth of China aster cv. White. Haryana Journal of Horticulture Sciences. 2010; 4(39):298-299.

25. Swaroop K, Raju DVS, Singh KP. Effect of nitrogen and phosphorus on growth, flowering and seed yield of African marigold (Tagetes erecta L.) cv. Pusa Narangi Gainda. Orissa Journal of Horticulture. 2007; 2(35):1520.

26. Tosar MV. Effect of spacing with different levels of nitrogen on growth and flower production of gaillardia (Gaillardia pulchella). M.Sc. (Agri.) thesis, Gujarat Agricultural University, sardarkrushinagar, 1989, 12-13. 